\title{
CHANGES IN REVEALED COMPARATIVE ADVANTAGE OF SOUTH KOREA AND HER MAJOR EUROPEAN UNION TRADING COUNTRIES
}

\author{
Kim Seung Jin and Kim GiSeung
}

\begin{abstract}
This paper analyzed how revealed comparative advantage (RCA) of South Korea and her major EU trading countries (i.e., France, Germany, Italy, Spain, and UK; FGISU in short hereafter) in the manufacturing sector changed over time for the period of 20002010 by using OECD International Trade by Commodity Statistics. In order to find major determinants of RCA of South Korea and FGISU, the correlation coefficients and multiple regression analyses were utilized. It was found that South Korea exported products which are less skilled human capital intensive and more R\&D intensive for the entire period. France is found to have exported products which are more physical capital intensive and more R\&D intensive for most of the period. It was found that Germany exported products which are more skilled human capital intensive for most of the period. Italy is also found to have exported products which are less physical (and skilled human) capital intensive and less R\&D intensive for the entire period. It was found that Spain exported products which are less R\&D intensive for the entire period. UK is also found to have exported products which are more physical (and skilled human) capital intensive and more R\&D intensive for the entire period. Therefore both South Korea and FGISU should try to export more of these products to the world market from now on.
\end{abstract}

Keywords: South Korea, European Union, comparative advantage, manufacturing sector, Newly Industrializing Economies

\section{Introduction}

The economy of South Korea has experienced dramatic changes during the last four decades. From a typical, underdeveloped agrarian economy of 1950s, South Korea emerged on the world stage as one of the front runners among the NIEs (Newly Industrializing Economies) in 1980s and now has become one of the major exporting countries of automobiles, iron and steel, electronic products, shipbuilding, and petrochemical products. This outstanding economic achievement is truly remarkable considering the poor endowment of natural resources and its small domestic market. For this reason, the economic development strategy of South Korea has been frequently referred to as a suitable model for other countries on the road to development.

According to Economic Statistics System of the Bank of Korea (i.e., ecos.bok.or.kr), GDP growth rates of South Korea, Germany, and the UK in 2012 dropped to $2.0 \%, 0.7 \%$, $0.1 \%$ respectively due to an economic recession engendered by a so-called European Union (EU) sovereign debt crisis. ${ }^{1}$ GDP growth rates of France, Italy, and Spain in 2012 dropped even further to $0.0 \%,-2.5 \%$, and $-1.6 \%$ respectively. According to Korean Trade Statistics published by the Korean International Trade Association (KITA) (i.e., kita.net),

1 Bank of Korea, Economic Statistics System (ecos.bok.or.kr), Seoul, Korea. 
South Korean exports to France in 2012 amounted to US\$2.60 billion (i.e., $0.5 \%$ of South Korea's total exports) and South Korean imports from France reached US\$ 4.92 billion (i.e., $0.9 \%$ of South Korea's total imports). ${ }^{2}$ Accordingly, South Korea suffered from US\$ 2.32 billion trade deficit with France. Likewise, South Korean exports to Germany in 2012 recorded US\$ 7.51 billion (i.e., 1.4\% of South Korea's total exports) and South Korean imports from Germany reached US\$ 17.65 billion (i.e., 3.4\% of South Korea's total imports). Consequently, South Korea suffered from US\$10.14 billion trade deficit with Germany. South Korean exports to Italy in 2012 recorded US\$ 3.26 billion (i.e., $0.6 \%$ of South Korea's total exports) and South Korean imports from Italy recorded US $\$ 4.83$ billion (i.e., $0.9 \%$ of South Korea's total imports). Consequently, South Korea suffered from US\$ 1.57 billion trade deficit with Italy. Likewise, South Korean exports to the UK in 2012 recorded US $\$ 4.90$ billion (i.e., $0.9 \%$ of Korea's total exports) and South Korean imports from the UK reached US\$ 6.37 billion (i.e., 1.2\% of South Korea's total imports). Accordingly, South Korea recorded US\$ 1.47 billion trade deficit with the UK. On the other hand, South Korean exports to Spain in 2012 recorded US\$ 1.67 billion (i.e., 0.3\% of South Korea's total exports) and South Korean imports from Spain recorded US\$1.29 billion (i.e., $0.2 \%$ of South Korea's total imports). Consequently, South Korea enjoyed US\$ 0.38 billion trade surplus with Spain.

Despite very close trade links between South Korea and her major EU trading countries (i.e., France, Germany, Italy, Spain, and the UK, FGISU in short hereafter), these countries are now suffering from an economic recession engendered by a socalled EU sovereign debt crisis as mentioned above. Therefore one way of overcoming the on-going economic recession in these six countries will be to further expand their trade volume. In this respect, it is very timely to analyze how revealed comparative advantage (RCA in short hereafter) of South Korea and her major EU trading countries in the manufacturing sector changed over time for the period of 2000-2010.

The paper aims to analyze how RCA of South Korea and her major EU trading countries in the manufacturing sector changed over time for the period of 2000-2010. For this purpose, Section 2 will briefly survey an RCA index developed by Balassa (1965) and methodology and research design of this paper will be explored in Section 3. ${ }^{3}$ Section 4 will measure RCA indices of South Korea and her major EU trading countries in the manufacturing sector for the period of 2000-2010 by using OECD (2012) trade matrix. The same section will also try to find the determinants of RCA indices of South Korea, France, Germany, Italy, Spain and the UK in the manufacturing sector for the last decade by utilizing both correlation coefficients and multiple regression analyses (Kim $(2002,2010) .{ }^{4}$ Section 5 will summarize major empirical results and conclude the paper with a few remarks.

Korean International Trade Association, Korean Trade Statistics (kita.net), Seoul, Korea.

Bela Balassa, "Trade Liberalization and Revealed Comparative Advantages," The Manchester School of Economic and Social Studies, Vol. 33, No. 2, 1965, pp. 91-123.

4 Kim Seung Jin, Trade Patterns between Korea and the United States: Overcoming Korea's Financial Crisis through Expanding her Trade Volume with the United States. International Trade and Business Institute, Seoul, Korea, 2002: Kim Seung Jin , "Changes in Comparative Advantage of OECD East European Countries and Korea," Eastern European Studies, Vol. 25, 2010, pp. 355-382. 


\section{Literature Review}

\section{1) Heckscher-Ohlin Theorem (i.e., Modern Version of Comparative Advantage Theorem)}

According to the Heckscher-Ohlin type of two-country-two-product-two-factor model, trade patterns between countries will be determined by the comparative advantage structures between two countries, determined by factor intensities of two products and factor endowment ratios of two countries. For example, Korea is relatively labor abundant and Germany is relatively capital abundant. Suppose that a product of X1 is relatively labor intensive and a product of $X 2$ is relatively capital intensive. Then Korea has a comparative advantage in the production of X1 and Germany has a comparative advantage in the production of $\mathrm{X} 2$ since before trade Korea can produce X1 at a lower cost vis-à-vis Germany and Germany can produce X2 at a lower cost vis-à-vis Korea. Since it is not so easy to measure prices of X1 and X2 empirically in an actual world due to heterogeneity of those products, Balassa (1965) introduced an RCA index as shown in the following section.

\section{2) RCA Index ${ }^{5}$}

To measure the international competitiveness of the i-th industry in the $\mathrm{j}$-th country, Balassa suggested an RCA index as follows: ${ }^{6}$

$$
\begin{aligned}
& R C A_{i}^{j}=\left(\left(E_{i}^{j} \mid W^{\prime} X_{i}\right) \mid\left(T E X^{j} \mid T W E X\right)\right) \cdot 100 \text {-------- (2-1) } \\
& \text { where } R C A_{i} \text { is an RCA index of the } i \text {-th industry in the } j \text {-th country, } \\
& E X_{i}^{j} \text { is the i-th industry's export value of the } j \text {-th country, } \\
& W E X_{i} \text { is the world's export value of the i-th industry, } \\
& T E X^{j} \text { is the total export value of the } j \text {-th country, } \\
& \text { TWEX is the world's total export value. }
\end{aligned}
$$

As the equation indicates, the $j$-th country will have a comparative advantage in the $i$-th industry if the value of $R C A_{i}^{j}$ is greater than 100 . On the contrary, the $j$-th country will have a comparative disadvantage in the $\mathrm{i}$-th industry if the value of $R C A_{i}^{j}$ is less than 100. Due to convenience of calculating an RCA index, many trade-related papers utilize the RCA index for measuring comparative advantage structure of trading countries. As stated above, this paper will not only measure RCA indices themselves but also try to find the determinants of RCA indices.

5 This RCA index is exactly equal to country i's export specialization index in commodity $h\left(S_{i}^{h}\right)$ which is defined by Yamazawa (1970) as follows.

$S_{i}^{h}=\frac{X_{i}^{h}}{X_{i}} / \frac{X^{h}}{X}$

where $X_{i}^{h}$. is country i's exports of the commodity h,

$X_{\text {. }}$ is country i's exports of all commodities,

$X^{h} .$. is world's total exports of the commodity $h$,

$X$. is world's total exports of all commodities.

6 Ippei Yamazawa, "Intensity analysis of world trade flow," Hitotsubashi Journal of Economics, Vol. 10, 970, pp. 61-90. 


\section{Data and Methodology}

\section{1) Data}

To calculate RCA indices of South Korea, France, Germany, Italy, Spain, and the UK in the manufacturing sector for the period of 2000-2010, we used the OECD International Trade by Commodity Statistics, which reports all the trade data between each and every member country and non-member countries of OECD from the viewpoint of OECD member countries. ${ }^{7}$ Since South Korea has been a member country of OECD ever since 1990s, it is quite appropriate for us to use an OECD trade statistics. As shown in Table 1, our basic sample of industries for the manufacturing sector consists of 35 industries at a SITC 2-digit level, which is an optimal sample size for our research. On top of that, the OECD trade matrix is now published for these 35 manufacturing industries.

\section{2) Methodology}

In order to find major determinants of RCA of South Korea, France, Germany, Italy, Spain, and the UK in the manufacturing sector for the period of 2000-2010, the following correlation coefficients and multiple regression analyses are used. The models for correlation analysis are as follows.

$R C A^{j}=f(P K L), R C A^{j}=f(S H K L), R C A^{j}=f(R D)$

Where, $R C A^{j}$ is the country j-th RCA index,

$P K L$ is a physical capital intensity defined as (physical capital)/(labor)ratio, $S H K L$ is a skilled human capital intensity defined as (skilled human capital)/(labor), $R D$ is an $R \& D$ intensity defined as ( $R \mathcal{E} D$ related expenditure)/(total sales value), $j=k$ (South Korea), $f$ (France), $g$ (Germany), $i$ (Italy), s(Spain), and $u($ United Kingdom).

Table 1 List of 35 Industries in the Manufacturing Sector

\begin{tabular}{l|l|l|l}
\hline $\begin{array}{l}\text { SITC } \\
\text { Code }\end{array}$ & Name of Industry & $\begin{array}{l}\text { SITC } \\
\text { Code }\end{array}$ & Name of Industry \\
\hline 51 & Organic Chemicals & 71 & $\begin{array}{l}\text { Power Generating Machinery } \\
\text { And Equipment }\end{array}$ \\
\hline 52 & Inorganic Chemicals & 72 & Specialized Machinery \\
\hline 53 & $\begin{array}{l}\text { Dyeing, Tanning } \\
\text { And Coloring Materials }\end{array}$ & 73 & Metal Working Machinery \\
\hline 54 & $\begin{array}{l}\text { Medicinal and Pharmaceutical Pro } \\
\text { ducts }\end{array}$ & 74 & Other Industrial Machinery and Parts \\
\hline 55 & Essential Oils and Perfume Materials & 75 & $\begin{array}{l}\text { Office Machines } \\
\text { And ADP Equipment }\end{array}$ \\
\hline 56 & Fertilizers & 76 & $\begin{array}{l}\text { Telecommunications } \\
\text { And Sound Recording Apparatus }\end{array}$ \\
\hline 57 & Plastics in Primary Forms & 77 & $\begin{array}{l}\text { Electrical Machinery, Apparatus } \\
\text { And Appliances, n.e.s. }\end{array}$ \\
\hline 58 & Plastics in Non-primary Forms & 78 & Road Vehicles \\
\hline 59 & Chemical Materials and Products, n.e.s. & 79 & Other Transport Equipments \\
\hline
\end{tabular}

7 OECD, International Trade by Commodity Statistics, Vol. 5, 2012. 


\begin{tabular}{l|l|l|l}
\hline 61 & $\begin{array}{l}\text { Leather, Leather Manufactures } \\
\text { And Dressed Furskins }\end{array}$ & 81 & $\begin{array}{l}\text { Prefabricated Buildings, Sanitary, } \\
\text { Heating and Lighting Fixtures, n.e.s. }\end{array}$ \\
\hline 62 & Rubber Manufactures, n.e.s. & 82 & Furniture and Parts Thereof \\
\hline 63 & $\begin{array}{l}\text { Cork and Wood Manufactures } \\
\text { (excluding Furniture) }\end{array}$ & 83 & Travel Goods, Handbags, etc. \\
\hline 64 & Paper and Paper Manufactures & 84 & $\begin{array}{l}\text { Articles of Apparel } \\
\text { And Clothing Accessories }\end{array}$ \\
\hline 65 & $\begin{array}{l}\text { Textile Yarn, Fabrics and Related } \\
\text { Products }\end{array}$ & 85 & Footwear \\
\hline 66 & $\begin{array}{l}\text { Non-metallic Mineral Manufactures, } \\
\text { n.e.s. }\end{array}$ & 87 & $\begin{array}{l}\text { Professional and Scientific } \\
\text { Instruments, n.e.s. }\end{array}$ \\
\hline 68 & Iron and Steel & 88 & $\begin{array}{l}\text { Photo Apparatus, Optical Goods, } \\
\text { Watches and Clocks }\end{array}$ \\
\hline 69 & Non-ferrous Metals & 89 & $\begin{array}{l}\text { Miscellaneous Manufactured Articles, } \\
\text { n.e.s. }\end{array}$ \\
\hline
\end{tabular}

To be specific, our correlation analysis model and hypotheses are as follows.

$$
\begin{aligned}
& R C A^{k}=f(P K L), R C A^{k}=f(S H K L), R C A^{k}=f(R D) \\
& \text { ? } \quad-\quad+ \\
& R C A^{f}=f(P K L), R C A^{f}=f(S H K L), R C A^{f}=f(R D) \\
& +\quad+\quad+ \\
& R C A^{g}=f(P K L), R C A^{g}=f(S H K L), R C A^{g}=f(R D) \\
& R C A^{i}=f(P K L), R C A^{i}=f(S H K L), R C A^{i}=f(R D) \\
& R C A^{s}=f(P K L), R C A^{s}=f(S H K L), R C A^{s}=f(R D) \\
& \text { ? ? - } \\
& R C A^{u}=f(P K L), R C A^{u}=f(S H K L), R C A^{u}=f(R D) \\
& +\quad+
\end{aligned}
$$

(Notice that the sign below an independent variable is an expected sign by our model, which are our hypotheses.)

For the multiple regression, the following log-linear models are estimated by OLS (ordinary least squares) method with assumption of no multicollinearity.

$$
\log \left(R C A^{j}\right)=\mathrm{A}_{1}+\mathrm{A}_{2} \cdot \log (P K L)+\mathrm{A}_{3} \cdot \log (S H K L)+\mathrm{A}_{4} \cdot \log (R D)
$$

Since independent variables of PKL and SHKL are highly correlated with each other, only SHKL and RDI are used in the process of multiple regression to overcome the multicollinearity problem in the following manner.

$$
\log \left(R C A^{j}\right)=\mathrm{A}_{1}+\mathrm{A}_{2} \cdot \log (S H K L)+\mathrm{A}_{3} \cdot \log (R D)
$$


To be specific, our multiple regression analysis model and hypotheses are as follows.

$$
\begin{aligned}
& \log \left(R C A^{k}\right)=\mathrm{A}_{1}+\mathrm{A}_{2} \cdot \log (S H K L)+\mathrm{A}_{3} \cdot \log (R D) \\
& \log \left(R C A^{f}\right)=\mathrm{A}_{1}+\mathrm{A}_{2} \cdot \log (S H K L)+\mathrm{A}_{3} \cdot \log (R D) \\
& \log \left(R C A^{g}\right)=\mathrm{A}_{1}+\mathrm{A}_{2} \cdot \log (S H K L)+\mathrm{A}_{3} \cdot \underset{+}{\log (R D)} \\
& \log \left(R C A^{i}\right)=\mathrm{A}_{1}+\mathrm{A}_{2} \cdot \log (S H K L)+\mathrm{A}_{3} \cdot \log (R D) \\
& \log \left(R C A^{s}\right)=\mathrm{A}_{1}+\mathrm{A}_{2} \cdot \log (S H K L)+\mathrm{A}_{3} \cdot \log (R D) \\
& \log \left(R C A^{u}\right)=\mathrm{A}_{1}+\mathrm{A}_{2} \cdot \log (S H K L)+\mathrm{A}_{3} \cdot \log (R D)
\end{aligned}
$$

(Notice that the sign below an independent variable is an expected sign by our model, which are our hypotheses.)

\section{Findings}

\section{1) Changes in RCA of South Korea and her Major EU Trading Countries in the Manufacturing} Sector

The numbers of industries whose RCA indices are greater than 100 and standard deviation of RCA indices in both South Korea and her major EU trading countries for the period of 2000-2010 are listed in Table 2. Throughout the entire period, Germany has comparative advantage in 19.0 industries while South Korea has comparative advantage in 9.8 industries on the average during the period of 2000-2010. This means that Germany has comparative advantage in the more diversified industries than South Korea during the period of 2000-2010.

As for an average value of standard deviation of each country's RCA during the period of 2000-2010, South Korea has the bigger value (i.e., 94.1) than Germany (i.e., 32.7). This again indicates that South Korea's export products are highly concentrated, while Germany's export products are more diversified. (It should be noted that the lower the standard deviation of RCA index of a certain country, the more diversified the export specialization pattern of the country, which was proved in pp. 65-66 in Yamazawa (1970).) Furthermore, South Korea's standard deviation of her RCA increased from 80.4 in 2000 to 99.1 in 2010, which means that South Korean exports became more concentrated over time in the period of 2000-2010. 
Table 2 Numbers of Industries Whose RCA Indices are Greater than 100 and Standard Deviation of RCA Indices in South Korea and her Major EU Trading Countries: 2000-2010

\begin{tabular}{|c|c|c|c|c|c|c|c|c|c|c|c|c|}
\hline \multirow[b]{2}{*}{ Year } & \multicolumn{6}{|c|}{$\begin{array}{l}\text { \# of Industries whose RCA Indices are } \\
\text { greater than } 100\end{array}$} & \multicolumn{6}{|c|}{ Standard Deviation of RCA } \\
\hline & $\begin{array}{l}\text { South } \\
\text { Korea }\end{array}$ & France & Germany & Italy & Spain & UK & $\begin{array}{l}\text { South } \\
\text { Korea }\end{array}$ & France & Germany & Italy & Spain & UK \\
\hline 2000 & 9 & 14 & 19 & 18 & 14 & 14 & 80.4 & 65.9 & 36.4 & 176.4 & 73.6 & 40.9 \\
\hline 2001 & 10 & 12 & 19 & 18 & 14 & 14 & 79.1 & 69.5 & 35.3 & 174.8 & 71.8 & 41.0 \\
\hline 2002 & 10 & 12 & 18 & 18 & 12 & 14 & 83.3 & 69.8 & 34.0 & 170.3 & 68.1 & 37.9 \\
\hline 2003 & 8 & 12 & 19 & 17 & 12 & 13 & 93.0 & 65.0 & 33.5 & 163.7 & 61.2 & 38.6 \\
\hline 2004 & 9 & 12 & 19 & 18 & 15 & 13 & 95.7 & 65.3 & 31.3 & 161.6 & 60.5 & 39.7 \\
\hline 2005 & 10 & 13 & 19 & 19 & 14 & 12 & 92.5 & 68.4 & 31.0 & 188.3 & 57.6 & 38.8 \\
\hline 2006 & 10 & 14 & 17 & 19 & 14 & 13 & 92.4 & 71.9 & 31.3 & 169.4 & 54.0 & 39.0 \\
\hline 2007 & 11 & 14 & 18 & 19 & 14 & 13 & 100.3 & 67.9 & 30.8 & 168.4 & 53.0 & 38.1 \\
\hline 2008 & 11 & 14 & 19 & 18 & 14 & 12 & 109.7 & 71.5 & 32.8 & 165.6 & 52.4 & 39.7 \\
\hline 2009 & 10 & 13 & 21 & 20 & 13 & 12 & 109.7 & 68.7 & 32.3 & 169.4 & 53.0 & 39.0 \\
\hline 2010 & 10 & 12 & 21 & 21 & 15 & 13 & 99.1 & 77.8 & 31.0 & 166.5 & 55.7 & 38.6 \\
\hline Average & 9.8 & 12.9 & 19.0 & 18.6 & 13.7 & 13.0 & 94.1 & 69.2 & 32.7 & 170.4 & 60.1 & 39.2 \\
\hline
\end{tabular}

On the other hand, Italy has the bigger value in standard deviation of their RCA (i.e., 170.4) than South Korea. This means that export products of Italy are highly concentrated, while South Korean export products are more diversified. Italy's standard deviation of her RCA, however, decreased from 176.4 in 2000 to 166.5 in 2010, which means that Italy's exports became more diversified over time in the period of 2000-2010.

As shown in Table 3, the Spearman (rank-order) correlation coefficient between 2010 RCA index and 2000 RCA index has the highest value in Italy (i.e., 0.95), which is followed by Spain (i.e., 0.91), France (i.e., 0.89), the UK (i.e., 0.85), Germany (i.e., 0.82), and South Korea (i.e., 0.68). This means that export patterns of South Korea changed faster than those of Germany, the UK, France, Spain, and Italy for the period of 2000-2010. On the other hand, export patterns of Italy remained the most stable in the same period.

Table 3 Spearman Correlation Coefficients between 2010 RCA Index and Respective Year's RCA Indices of South Korea and her Major EU Trading Countries: 2000-20091

\begin{tabular}{c|cccccc}
\hline Year & South Korea & France & Germany & Italy & Spain & UK \\
\hline 2000 & $0.68^{* * *}$ & $0.89^{* * *}$ & $0.82^{* * *}$ & $0.95^{* * *}$ & $0.91^{* * *}$ & $0.85^{* * *}$ \\
2001 & $0.66^{* * *}$ & $0.89^{* * *}$ & $0.82^{* * *}$ & $0.97^{* * *}$ & $0.90^{* * *}$ & $0.87^{* * *}$ \\
2002 & $0.72^{* * *}$ & $0.91^{* * *}$ & $0.83^{* * *}$ & $0.98^{* * *}$ & $0.91^{* * *}$ & $0.80^{* * *}$ \\
2003 & $0.78^{* * *}$ & $0.92^{* * *}$ & $0.84^{* * *}$ & $0.98^{* * *}$ & $0.93^{* * *}$ & $0.87^{* * *}$ \\
2004 & $0.84^{* * *}$ & $0.94^{* * *}$ & $0.89^{* * *}$ & $0.98^{* * *}$ & $0.94^{* * *}$ & $0.87^{* * *}$ \\
2005 & $0.91^{* * *}$ & $0.95^{* * *}$ & $0.90^{* * *}$ & $0.98^{* * *}$ & $0.93^{* * *}$ & $0.87^{* * *}$ \\
2006 & $0.93^{* * *}$ & $0.96^{* * *}$ & $0.91^{* * *}$ & $0.99^{* * *}$ & $0.93^{* * *}$ & $0.95^{* * *}$ \\
2007 & $0.96^{* * *}$ & $0.98^{* * *}$ & $0.92^{* * *}$ & $0.99^{* * *}$ & $0.96^{* * *}$ & $0.94^{* * *}$ \\
2008 & $0.97^{* * *}$ & $0.98^{* * *}$ & $0.93^{* * *}$ & $0.99^{* * *}$ & $0.96^{* * *}$ & $0.96^{* * *}$ \\
2009 & $0.98^{* * *}$ & $0.99^{* * *}$ & $0.94^{* * *}$ & $0.99^{* * *}$ & $0.96^{* * *}$ & $0.97^{* * *}$ \\
\hline
\end{tabular}

1) ${ }^{\prime \prime \prime}$ indicates that the coefficients are statistically significant at the 10 percent level, ${ }^{\prime *}{ }^{\prime} 5$ percent level, and

$\iota^{\prime * * * \prime} 1$ percent level, respectively. The same notation will be used hereafter. 
Table 4 displays the Spearman correlation coefficients between South Korea's 2010 RCA index and respective year's RCA index of FGISU (i.e., France, Germany, Italy, Spain, and the UK in short hereafter). By looking at this table, we can guess which year of FGISU's export patterns the South Korean export patterns most likely resemble. South Korea's 2010 RCA index has insignificant Spearman correlation coefficients with FGU (i.e., France, Germany, and the UK in short hereafter) for the period of 2000-2010. This means that South Korea's export patterns do not resemble those of FGU due to the differences in factor endowment ratios of South Korea and FGU.

On the other hand, South Korea's 2010 RCA index has significantly negative Spearman correlation coefficients with Spain throughout the entire period of 2000-2010. This means that both Spain and South Korea had opposite export patterns due to the strong differences in factor endowment ratios of Spain and South Korea. Furthermore, South Korea's 2010 RCA index has the highest negative Spearman correlation coefficient with Spain's 2010 RCA index. This implies that export patterns of South Korea in 2010 were most opposite to those of Spain in 2010. It was also found that South Korea's 2010 RCA index has significantly negative Spearman correlation coefficients with Italy for the period of 2000-2002.

Table 4 Spearman Correlation Coefficients between South Korea's 2010 RCA Index and Respective Year's RCA Indices of her Major EU Trading Countries: 2000-2010

\begin{tabular}{c|c|c|ccc}
\hline Year & $\begin{array}{c}\text { South Korea's } \\
\text { 2010 and } \\
\text { France's } \\
\text { Respective Year }\end{array}$ & $\begin{array}{c}\text { South Korea's } \\
\text { 2010 and } \\
\text { Germany's } \\
\text { Respective Year }\end{array}$ & $\begin{array}{c}\text { South Korea's } \\
\text { 2010 and Italy's } \\
\text { Respective } \\
\text { Year }\end{array}$ & $\begin{array}{c}\text { South Korea's } \\
\text { 2010 and } \\
\text { Spain's } \\
\text { Respective Year }\end{array}$ & $\begin{array}{c}\text { South Korea's } \\
\text { 2010 and UK's } \\
\text { Respective Year }\end{array}$ \\
\hline 2000 & -0.08 & 0.16 & $-0.35^{* *}$ & $-0.45^{* * *}$ & 0.20 \\
2001 & -0.07 & 0.19 & $-0.31^{*}$ & $-0.44^{* * *}$ & 0.19 \\
2002 & -0.05 & 0.16 & $-0.29^{*}$ & $-0.44^{* * *}$ & 0.19 \\
2003 & -0.04 & 0.20 & -0.27 & $-0.44^{* * *}$ & 0.07 \\
2004 & -0.07 & 0.17 & -0.27 & $-0.43^{* *}$ & 0.09 \\
2005 & -0.08 & 0.15 & -0.26 & $-0.44^{* * *}$ & 0.14 \\
2006 & -0.07 & 0.14 & -0.24 & $-0.40^{* *}$ & 0.15 \\
2007 & -0.10 & 0.10 & -0.23 & $-0.40^{* *}$ & 0.10 \\
2008 & -0.08 & 0.07 & -0.25 & $-0.42^{* *}$ & 0.10 \\
2009 & -0.12 & 0.03 & -0.23 & $-0.41^{* *}$ & 0.12 \\
2010 & -0.13 & 0.16 & -0.23 & $-0.50^{* * *}$ & 0.04 \\
\hline
\end{tabular}

The Spearman correlation coefficients between South Korea's RCA index and FGISU's RCA indices respectively for the period of 2000-2010 are displayed in Table 5. South Korea's RCA index has insignificant correlation coefficients with RCA indices of FGIU (i.e., France, Germany, Italy, and the UK in short hereafter) for the period of 2000-2010, which means that South Korean export pattern is not similar to FGIU's export patterns. This implies that South Korea can increase her exports to FGIU by exploiting non-similarity of South Korean and FGIU's export patterns. The Spearman correlation coefficients between South Korea's RCA index and Spain's RCA index, however, are negatively significant for the period of 2007-2010 and their values have been increasing over time. This again means that Spain and South Korea had opposite export patterns due to the strong differences in factor endowment ratios of Spain and South Korea. Especially, South Korean export patterns became increasingly opposite 
to Spanish export patterns over time for the period of 2007-2010. This again implies that South Korea can increase her exports to Spain by exploiting opposite relations of South Korean and Spanish export patterns.

Table 5 Spearman Correlation Coefficients between South Korea's RCA Index and her Major EU Trading Countries' RCA Index: 2000-2010

\begin{tabular}{c|c|c|ccc}
\hline Year & $\begin{array}{c}\text { Korea and } \\
\text { France }\end{array}$ & $\begin{array}{c}\text { Korea and } \\
\text { Germany }\end{array}$ & Korea and Italy & Korea and Spain & Korea and UK \\
\hline 2000 & -0.03 & -0.22 & 0.05 & -0.07 & -0.06 \\
2001 & -0.02 & -0.17 & 0.10 & -0.01 & -0.04 \\
2002 & 0.03 & -0.18 & 0.06 & -0.04 & -0.03 \\
2003 & 0.07 & -0.03 & 0.04 & -0.08 & -0.13 \\
2004 & -0.07 & -0.03 & 0.03 & -0.12 & -0.11 \\
2005 & -0.06 & 0.07 & -0.07 & -0.19 & 0.05 \\
2006 & -0.10 & 0.06 & -0.18 & -0.28 & 0.10 \\
2007 & -0.16 & 0.11 & -0.19 & $-0.30^{*}$ & 0.05 \\
2008 & -0.12 & 0.02 & -0.27 & $-0.35^{* *}$ & 0.07 \\
2009 & -0.13 & -0.03 & -0.26 & $-0.35^{* *}$ & 0.10 \\
2010 & -0.13 & 0.16 & -0.23 & $-0.50^{* * *}$ & 0.04 \\
\hline
\end{tabular}

2) RCA Determinants of South Korea and her Major EU Trading Countries in the Manufacturing Sector

RCA Determinants of South Korea

For the entire period of 2000-2010, an $R C A^{k}$ variable has (a) negative correlation coefficients with PKL and SHKL and (b) positive correlation coefficients with RD (Table 6). Furthermore, significantly negative correlation coefficients were found in the cases of both simple and Spearman rank correlation coefficients between $R C A^{k}$ and SHKL for the period of 2000-2004, which means that South Korea exported products which are less skilled human capital intensive for those years. On top of that, significantly positive correlation coefficients were found in the cases of both simple and Spearman rank correlation coefficients between $R C A^{k}$ and RD for the period of 2006-2010, which means that South Korea exported more R\&D intensive products for the period. ${ }^{8}$

8 The only exception is a simple correlation coefficient for the year of 2007, which is insignificant. $R C A^{k}$, however, has a significantly positive simple correlation coefficient with RD for the year of 2004. 
Table 6 Correlation Coefficients Between $R C A^{k}$ and Industrial Characteristics Variables: 2000-2010

\begin{tabular}{|c|c|c|c|c|}
\hline \multirow[t]{2}{*}{ Year } & \multirow{2}{*}{$\begin{array}{l}\text { Correlation } \\
\text { Coefficients }\end{array}$} & \multicolumn{3}{|c|}{ Industrial Characteristics Variables related to $R C A^{k}$} \\
\hline & & PKL & SHKL & RD \\
\hline \multirow[t]{2}{*}{2000} & Simple & -0.23 & $-0.41^{* *}$ & 0.01 \\
\hline & Spearman & -0.28 & $-0.37^{* *}$ & 0.03 \\
\hline \multirow[t]{2}{*}{2001} & Simple & -0.24 & $-0.43^{* *}$ & 0.03 \\
\hline & Spearman & -0.25 & $-0.41^{* *}$ & 0.07 \\
\hline \multirow[t]{2}{*}{2002} & Simple & -0.23 & $-0.38^{* *}$ & 0.15 \\
\hline & Spearman & -0.23 & $-0.40^{* *}$ & 0.11 \\
\hline \multirow[t]{2}{*}{2003} & Simple & -0.21 & $-0.33^{*}$ & 0.27 \\
\hline & Spearman & -0.21 & $-0.35^{* *}$ & 0.16 \\
\hline \multirow[t]{2}{*}{2004} & Simple & -0.18 & $-0.28^{*}$ & $0.29^{*}$ \\
\hline & Spearman & -0.23 & $-0.30^{*}$ & 0.18 \\
\hline \multirow[t]{2}{*}{2005} & Simple & -0.16 & -0.27 & 0.27 \\
\hline & Spearman & -0.15 & -0.21 & 0.25 \\
\hline \multirow[t]{2}{*}{2006} & Simple & -0.17 & -0.23 & $0.42^{* *}$ \\
\hline & Spearman & -0.16 & -0.16 & $0.31^{*}$ \\
\hline \multirow[t]{2}{*}{2007} & Simple & -0.15 & -0.23 & 0.27 \\
\hline & Spearman & -0.11 & -0.13 & $0.33^{*}$ \\
\hline \multirow[t]{2}{*}{2008} & Simple & -0.10 & -0.18 & $0.41^{* *}$ \\
\hline & Spearman & -0.02 & -0.04 & $0.41^{* *}$ \\
\hline \multirow[t]{2}{*}{2009} & Simple & -0.12 & -0.18 & $0.45^{* * *}$ \\
\hline & Spearman & -0.02 & -0.07 & $0.42^{* *}$ \\
\hline \multirow[t]{2}{*}{2010} & Simple & -0.12 & -0.19 & $0.53^{* * *}$ \\
\hline & Spearman & -0.02 & -0.07 & $0.44^{* * *}$ \\
\hline
\end{tabular}

1) ${ }^{\star * \prime}$ indicates that the coefficients are statistically significant at the 10 percent level, ‘**' 5 percent level, and $\star_{* * * \prime} 1$ percent level, respectively. The same notation will be used hereafter.

According to multiple regressions results of South Korea, the coefficients of SHKL and RD turn out to be significantly negative and positive respectively for the entire period of 2000-2010 (Table 7). ${ }^{9}$ This proves that South Korea exported products which are less skilled human capital and more R\&D intensive for the entire period of 2000-2010.

9 The only exception is a coefficient of RD for the year of 2000, which is not significant. 
Table 7 Multiple Regression with $\log \left(R C A^{k}\right)$ as a Dependent Variable: 2000-2010

\begin{tabular}{|c|c|c|c|c|c|c|}
\hline \multirow[t]{2}{*}{ Year } & \multicolumn{2}{|c|}{ Independent variables } & \multirow[t]{2}{*}{ Constant } & \multicolumn{3}{|c|}{ Test Stat. } \\
\hline & $\log (S H K L)$ & $\log (R D)$ & & $\mathbf{R}^{2}$ & F test & Prob $>F$ \\
\hline 2000 & $\begin{array}{l}-1.06^{* * *} \\
(0.30)\end{array}$ & $\begin{array}{l}0.32 \\
(0.20)\end{array}$ & $\begin{array}{l}3.50^{* * *} \\
(0.25)\end{array}$ & 0.29 & 6.48 & 0.00 \\
\hline 2001 & $\begin{array}{l}-1.09^{* * *} \\
(0.29)\end{array}$ & $\begin{array}{l}0.36^{*} \\
(0.19)\end{array}$ & $\begin{array}{l}3.50^{* * *} \\
(0.24)\end{array}$ & 0.31 & 7.22 & 0.00 \\
\hline 2002 & $\begin{array}{l}-1.07^{* * *} \\
(0.29)\end{array}$ & $\begin{array}{l}0.44^{\star *} \\
(0.19)\end{array}$ & $\begin{array}{l}3.43^{* * *} \\
(0.24)\end{array}$ & 0.31 & 7.27 & 0.00 \\
\hline 2003 & $\begin{array}{l}-1.10^{* * *} \\
(0.30)\end{array}$ & $\begin{array}{l}0.54^{* *} \\
(0.20)\end{array}$ & $\begin{array}{l}3.29^{* * * *} \\
(0.25)\end{array}$ & 0.32 & 7.36 & 0.00 \\
\hline 2004 & $\begin{array}{l}-1.00^{* * *} \\
(0.31)\end{array}$ & $\begin{array}{l}0.59^{* * *} \\
(0.21)\end{array}$ & $\begin{array}{l}3.22^{* * *} \\
(0.26)\end{array}$ & 0.29 & 6.39 & 0.00 \\
\hline 2005 & $\begin{array}{l}-0.91^{* * *} \\
(0.30)\end{array}$ & $\begin{array}{l}0.60 \text { *** } \\
(0.21)\end{array}$ & $\begin{array}{l}3.28^{* * *} \\
(0.26)\end{array}$ & 0.26 & 5.77 & 0.00 \\
\hline 2006 & $\begin{array}{l}-0.91^{* * *} \\
(0.32)\end{array}$ & $\begin{array}{l}0.69^{* * *} \\
(0.21)\end{array}$ & $\begin{array}{l}3.20^{* * *} \\
(0.27)\end{array}$ & 0.28 & 6.34 & 0.00 \\
\hline 2007 & $\begin{array}{l}-0.90^{* * *} \\
(0.31)\end{array}$ & $\begin{array}{l}0.67^{* * *} \\
(0.21)\end{array}$ & $\begin{array}{l}3.22^{* * *} \\
(0.26)\end{array}$ & 0.28 & 6.30 & 0.00 \\
\hline 2008 & $\begin{array}{l}-0.73^{* *} \\
(0.30)\end{array}$ & $\begin{array}{l}0.72^{\star * *} \\
(0.20)\end{array}$ & $\begin{array}{l}3.29^{* * *} \\
(0.25)\end{array}$ & 0.30 & 6.73 & 0.00 \\
\hline 2009 & $\begin{array}{l}-0.76^{* *} \\
(0.30)\end{array}$ & $\begin{array}{l}0.74^{* * *} \\
(0.20)\end{array}$ & $\begin{array}{l}3.27^{* * *} \\
(0.25)\end{array}$ & 0.31 & 7.32 & 0.00 \\
\hline 2010 & $\begin{array}{l}-0.80 \text { ** } \\
(0.30)\end{array}$ & $\begin{array}{l}0.74^{\star * *} \\
(0.20)\end{array}$ & $\begin{array}{l}3.28^{* * *} \\
(0.25)\end{array}$ & 0.31 & 7.31 & 0.00 \\
\hline
\end{tabular}

1) Standard errors in parentheses. ${ }^{\prime \prime \prime}$ indicates that the coefficients are statistically significant at the 10 percent level, ${ }^{\prime * * \prime} 5$ percent level, and ${ }^{\prime * * * \prime} 1$ percent level, respectively. The same notation will be used hereafter.

\section{RCA Determinants of France}

For the entire period of 2000-2010, a $R C A^{f}$ variable has (a) significantly positive Spearman correlation coefficients with PKL for the period of 2000-2004 and (b) significantly positive simple correlation coefficients with RD for the period of 2000-2002 and 2006-2007 (Table 8 ). This means that France exported products which are more physical capital intensive and more R\&D intensive products for those years respectively. 
Table 8 Correlation Coefficients between $R C A^{f}$ and Industrial Characteristics Variables: 2000-2010

\begin{tabular}{l|l|l|l|l}
\hline \multirow{2}{*}{ Year } & \multirow{2}{*}{\begin{tabular}{l} 
Correlation \\
\cline { 3 - 5 }
\end{tabular}} & Coefficients & \multicolumn{3}{|c}{ Characteristics Variables related to RCA $^{f}$} \\
\cline { 3 - 5 } & & PKL & SHKL & RD \\
\hline 2000 & Simple & 0.09 & -0.02 & $0.35^{* *}$ \\
& Spearman & $0.33^{*}$ & 0.14 & 0.02 \\
\hline 2001 & Simple & 0.07 & -0.02 & $0.37^{* *}$ \\
& Spearman & $0.35^{* *}$ & 0.17 & 0.04 \\
\hline 2002 & Simple & 0.05 & -0.06 & $0.32^{*}$ \\
& Spearman & $0.34^{* *}$ & 0.17 & 0.05 \\
\hline 2003 & Simple & 0.06 & -0.06 & 0.24 \\
& Spearman & $0.31^{*}$ & 0.16 & 0.02 \\
\hline 2004 & Simple & 0.03 & -0.10 & 0.23 \\
& Spearman & $0.30^{*}$ & 0.13 & 0.04 \\
\hline 2005 & Simple & 0.02 & -0.10 & 0.23 \\
& Spearman & 0.27 & 0.09 & 0.01 \\
\hline 2006 & Simple & 0.02 & -0.10 & $0.30^{*}$ \\
& Spearman & 0.26 & 0.08 & 0.01 \\
\hline 2007 & Simple & 0.01 & -0.11 & $0.29^{*}$ \\
& Spearman & 0.26 & 0.05 & 0.01 \\
\hline 2008 & Simple & 0.03 & -0.11 & 0.25 \\
& Spearman & 0.25 & 0.04 & 0.01 \\
\hline 2009 & Simple & 0.01 & -0.09 & 0.24 \\
& Spearman & 0.23 & 0.07 & -0.02 \\
\hline 2010 & Simple & 0.01 & 0.04 & 0.27 \\
& Spearman & 0.21 & & \\
\hline
\end{tabular}

According to multiple regressions results of France, the coefficients of SHKL and RD turn out to be insignificantly negative and positive respectively for the entire period of 2000-2010 (Table 9). 
Table 9 Multiple Regression with $\log \left(R C A^{f}\right)$ as a Dependent Variable: 2000-2010

\begin{tabular}{|c|c|c|c|c|c|c|}
\hline \multirow{2}{*}{ Year } & \multicolumn{2}{|c|}{ Independent variables } & \multirow{2}{*}{ Constant } & \multicolumn{3}{|c|}{ Test Stat. } \\
\hline & $\log (\mathrm{SHKL})$ & $\log (\mathrm{RD})$ & & $\mathbf{R}^{2}$ & Ftest & Prob $>F$ \\
\hline \multirow[t]{2}{*}{2000} & -0.06 & 0.06 & $4.50^{\text {k*k }}$ & 0.01 & 0.19 & 0.82 \\
\hline & (0.16) & $(0.10)$ & $(0.13)$ & & & \\
\hline \multirow[t]{2}{*}{2001} & -0.06 & 0.08 & $4.48^{\star \star *}$ & 0.02 & 0.25 & 0.78 \\
\hline & (0.16) & $(0.11)$ & $(0.13)$ & & & \\
\hline \multirow[t]{2}{*}{2002} & -0.11 & 0.07 & $4.46^{* * *}$ & 0.02 & 0.29 & 0.75 \\
\hline & (0.16) & $(0.11)$ & (0.14) & & & \\
\hline \multirow[t]{2}{*}{2003} & -0.10 & 0.06 & $4.45^{* * *}$ & 0.01 & 0.23 & 0.80 \\
\hline & $(0.16)$ & $(0.11)$ & $(0.13)$ & & & \\
\hline \multirow[t]{2}{*}{2004} & -0.13 & 0.06 & $4.45^{\star * *}$ & 0.02 & 0.34 & 0.71 \\
\hline & (0.16) & $(0.11)$ & $(0.13)$ & & & \\
\hline \multirow[t]{2}{*}{2005} & -0.13 & 0.04 & $4.48^{* * *}$ & 0.02 & 0.28 & 0.76 \\
\hline & (0.17) & $(0.11)$ & $(0.14)$ & & & \\
\hline \multirow[t]{2}{*}{2006} & -0.14 & 0.06 & $4.46^{* * *}$ & 0.02 & 0.35 & 0.71 \\
\hline & $(0.17)$ & $(0.11)$ & $(0.14)$ & & & \\
\hline \multirow[t]{2}{*}{2007} & -0.11 & 0.04 & $4.48^{\text {** }}$ & 0.01 & 0.24 & 0.79 \\
\hline & $(0.17)$ & $(0.11)$ & (0.14) & & & \\
\hline \multirow[t]{2}{*}{2008} & -0.12 & 0.03 & $4.50^{\star * *}$ & 0.02 & 0.25 & 0.78 \\
\hline & $(0.17)$ & (0.11) & (0.14) & & & \\
\hline \multirow[t]{2}{*}{2009} & -0.08 & 0.01 & $4.50^{\star \star *}$ & 0.01 & 0.12 & 0.89 \\
\hline & (0.17) & (0.12) & $(0.14)$ & & & \\
\hline \multirow[t]{2}{*}{2010} & -0.13 & 0.03 & $4.47^{* * *}$ & 0.02 & 0.28 & 0.76 \\
\hline & (0.18) & (0.12) & $(0.15)$ & & & \\
\hline
\end{tabular}

1) Standard errors in parentheses.

\section{RCA Determinants of Germany}

For the entire period of 2000-2010, a $R C A^{g}$ variable has positive correlation coefficients with SHKL (Table 10). Furthermore, significantly positive correlation coefficients were found in the cases of Spearman rank correlation coefficients between $R C A^{g}$ and SHKL for the period of 2000-2007, which means that Germany exported products which are more skilled human capital intensive for those years. 
Table 10 Correlation Coefficients between RCAg and Industrial Characteristics Variables: 2000-2010

\begin{tabular}{|c|c|c|c|c|}
\hline \multirow[t]{2}{*}{ Year } & \multirow{2}{*}{$\begin{array}{l}\text { Correlation } \\
\text { Coefficients }\end{array}$} & \multicolumn{3}{|c|}{ Industrial Characteristics Variables related to $R C A^{g}$} \\
\hline & & PKL & SHKL & RD \\
\hline \multirow[t]{2}{*}{2000} & Simple & 0.11 & 0.24 & 0.01 \\
\hline & Spearman & 0.27 & $0.44^{* * *}$ & 0.17 \\
\hline \multirow[t]{2}{*}{2001} & Simple & 0.07 & 0.24 & -0.01 \\
\hline & Spearman & 0.27 & $0.44^{* \star *}$ & 0.19 \\
\hline \multirow[t]{2}{*}{2002} & Simple & 0.09 & 0.26 & -0.05 \\
\hline & Spearman & 0.27 & $0.45^{* * *}$ & 0.21 \\
\hline \multirow[t]{2}{*}{2003} & Simple & 0.05 & 0.20 & -0.03 \\
\hline & Spearman & 0.23 & $0.39^{* *}$ & 0.22 \\
\hline \multirow[t]{2}{*}{2004} & Simple & 0.02 & 0.20 & -0.02 \\
\hline & Spearman & 0.20 & $0.36^{* *}$ & 0.22 \\
\hline \multirow[t]{2}{*}{2005} & Simple & 0.01 & 0.16 & -0.04 \\
\hline & Spearman & 0.18 & $0.34^{* *}$ & 0.21 \\
\hline \multirow[t]{2}{*}{2006} & Simple & 0.01 & 0.14 & -0.09 \\
\hline & Spearman & 0.16 & $0.30^{*}$ & 0.20 \\
\hline \multirow[t]{2}{*}{2007} & Simple & -0.02 & .014 & -0.06 \\
\hline & Spearman & 0.13 & $0.29^{*}$ & 0.19 \\
\hline \multirow[t]{2}{*}{2008} & Simple & -0.01 & 0.14 & -0.08 \\
\hline & Spearman & 0.10 & 0.26 & 0.18 \\
\hline \multirow[t]{2}{*}{2009} & Simple & -0.06 & 0.11 & -0.10 \\
\hline & Spearman & 0.05 & 0.25 & 0.08 \\
\hline \multirow[t]{2}{*}{2010} & Simple & -0.07 & 0.08 & 0.08 \\
\hline & Spearman & 0.06 & 0.24 & 0.19 \\
\hline
\end{tabular}

According to multiple regressions results of Germany, the coefficients of SHKL turn out to be significantly positive for the period of 2000-2002 and 2008 (Table 11). This proves that Germany exported products which are more SHKL intensive for those years. 
Table 11 Multiple Regression with $\log \left(R C A^{g}\right)$ as a Dependent Variable: 2000-2010

\begin{tabular}{lllllcc}
\hline \multirow{2}{*}{ Year } & \multicolumn{2}{c}{ Independent variables } & Constant & \multicolumn{3}{c}{ Test Stat. } \\
& $\log ($ SHKL) & $\log (\mathbf{R D})$ & & F test & Prob > F \\
\hline 2000 & $0.21^{*}$ & 0.04 & $4.61^{* * *}$ & 0.17 & 3.17 & 0.06 \\
& $(0.11)$ & $(0.08)$ & $(0.09)$ & & & \\
2001 & $0.21^{*}$ & 0.04 & $4.59^{* * *}$ & 0.17 & 3.30 & 0.05 \\
& $(0.11)$ & $(0.07)$ & $(0.09)$ & & & \\
2002 & $0.23^{* *}$ & 0.03 & $4.60^{* * *}$ & 0.18 & 3.61 & 0.04 \\
& $(0.11)$ & $(0.07)$ & $(0.09)$ & & & \\
2003 & 0.18 & 0.06 & $4.57^{* * *}$ & 0.16 & 3.01 & 0.06 \\
& $(0.11)$ & $(0.07)$ & $(0.09)$ & & & \\
2004 & 0.17 & 0.05 & $4.57^{* * *}$ & 0.16 & 2.96 & 0.07 \\
& $(0.10)$ & $(0.07)$ & $(0.08)$ & & & \\
2005 & 0.16 & 0.03 & $4.59^{* * *}$ & 0.13 & 2.31 & 0.12 \\
& $(0.10)$ & $(0.07)$ & $(0.08)$ & & & \\
2006 & 0.15 & 0.02 & $4.59^{* * *}$ & 0.09 & 1.65 & 0.21 \\
& $(0.10)$ & $(0.07)$ & $(0.09)$ & & & \\
2007 & 0.16 & 0.01 & $4.60^{* * *}$ & 0.10 & 1.70 & 0.20 \\
& $(0.10)$ & $(0.07)$ & $(0.09)$ & & & \\
2008 & $0.19^{*}$ & -0.01 & $4.65^{* * *}$ & 0.10 & 1.75 & 0.19 \\
& $(0.11)$ & $(0.07)$ & $(0.09)$ & & & \\
& 0.18 & -0.03 & $4.68^{* * *}$ & 0.09 & 1.53 & 0.23 \\
& $(0.11)$ & $(0.07)$ & $(0.09)$ & & & \\
& 0.14 & 0.02 & $4.64^{* * *}$ & 0.08 & 1.45 & 0.25 \\
& $(0.11)$ & $(0.07)$ & $(0.09)$ & & & \\
\hline
\end{tabular}

1) Standard errors in parentheses.

\section{RCA Determinants of Italy}

For the entire period of 2000-2010, the results show significantly negative relationships between a $R C A^{i}$ variable and all three ind ustrial characteristics variables (i.e., PKL, SHKL, and RD) (Table 12). This means that Italy exported less physical (and skilled human) capital intensive products and less R\&D intensive products for the whole period. 
Table 12 Correlation Coefficients between $R C A^{i}$ and Industrial Characteristics Variables: 2000-2010

\begin{tabular}{|c|c|c|c|c|}
\hline \multirow[t]{2}{*}{ Year } & \multirow{2}{*}{$\begin{array}{l}\text { Correlation } \\
\text { Coefficients }\end{array}$} & \multicolumn{3}{|c|}{ Industrial Characteristics Variables related to $R C A^{i}$} \\
\hline & & PKL & SHKL & RD \\
\hline \multirow[t]{2}{*}{2000} & Simple & $-0.31^{*}$ & $-0.40^{* *}$ & $-0.37^{* *}$ \\
\hline & Spearman & $-0.42 * *$ & $-0.43^{* * *}$ & $-0.55^{* * *}$ \\
\hline \multirow[t]{2}{*}{2001} & Simple & $-0.32^{*}$ & $-0.41^{* *}$ & $-0.38^{* *}$ \\
\hline & Spearman & $-0.41^{* *}$ & $-0.45^{* * *}$ & $-0.55^{* * *}$ \\
\hline \multirow[t]{2}{*}{2002} & Simple & $-0.32^{* *}$ & $-0.41^{* *}$ & $-0.38^{* *}$ \\
\hline & Spearman & $-0.42^{* *}$ & $-0.47^{* * *}$ & $-0.55^{* * *}$ \\
\hline \multirow[t]{2}{*}{2003} & Simple & $-0.32^{*}$ & $-0.42^{* *}$ & $-0.39 * *$ \\
\hline & Spearman & $-0.41^{* *}$ & $-0.48^{* * *}$ & $-0.54^{* * *}$ \\
\hline \multirow[t]{2}{*}{2004} & Simple & $-0.31^{*}$ & $-0.41^{* *}$ & $-0.39 * *$ \\
\hline & Spearman & $-0.39^{* *}$ & $-0.46^{* * *}$ & $-0.52^{* * *}$ \\
\hline \multirow[t]{2}{*}{2005} & Simple & $-0.30^{*}$ & $-0.41^{* *}$ & $-0.36^{* *}$ \\
\hline & Spearman & $-0.39 * *$ & $-0.49^{* * *}$ & $-0.51^{* * *}$ \\
\hline \multirow[t]{2}{*}{2006} & Simple & $-0.31^{*}$ & $-0.41^{* *}$ & $-0.37^{* *}$ \\
\hline & Spearman & $-0.38^{* *}$ & $-0.47^{* \star *}$ & $-0.49^{* * *}$ \\
\hline \multirow[t]{2}{*}{2007} & Simple & $-0.31^{*}$ & $-0.41^{* *}$ & $-0.37^{* *}$ \\
\hline & Spearman & $-0.39^{* *}$ & $-0.48^{* * *}$ & $-0.50^{* * *}$ \\
\hline \multirow[t]{2}{*}{2008} & Simple & $-0.31^{*}$ & $-0.41^{* *}$ & $-0.37^{* *}$ \\
\hline & Spearman & $-0.38^{* *}$ & $-0.46^{* * *}$ & $-0.50^{* * *}$ \\
\hline \multirow[t]{2}{*}{2009} & Simple & $-0.31^{*}$ & $-0.40^{* *}$ & $-0.37^{* *}$ \\
\hline & Spearman & $-0.40^{* *}$ & $-0.47^{\star * *}$ & $-0.52^{* * *}$ \\
\hline \multirow[t]{2}{*}{2010} & Simple & $-0.30^{*}$ & $-0.40^{* *}$ & $-0.36^{* *}$ \\
\hline & Spearman & $-0.38^{\star *}$ & $-0.46^{* * *}$ & $-0.52^{* * *}$ \\
\hline
\end{tabular}

According to multiple regressions results of Italy, the coefficients of SHKL and RD turn out to be significantly negative for the entire period of 2000-2010 (Table 13). This proves that Italy exported products which are less skilled human capital intensive and less R\&D intensive for the whole period. 
Table 13 Multiple Regressions with $\log \left(R C A^{i}\right)$ as a Dependent Variable: 2000-2010 ${ }^{1}$

\begin{tabular}{|c|c|c|c|c|c|c|}
\hline \multirow{2}{*}{ Year } & \multicolumn{2}{|c|}{ Independent variables } & \multirow{2}{*}{ Constant } & \multicolumn{3}{|c|}{ Test Stat. } \\
\hline & $\log (\mathrm{SHKL})$ & $\log (\mathrm{RD})$ & & $\mathbf{R}^{2}$ & F test & Prob $>F$ \\
\hline \multirow[t]{2}{*}{2000} & $-0.52^{* *}$ & $-0.39^{* *}$ & $4.95^{* * *}$ & 0.40 & 10.58 & 0.00 \\
\hline & $(0.24)$ & $(0.16)$ & $(0.20)$ & & & \\
\hline \multirow[t]{2}{*}{2001} & $-0.58^{* *}$ & $-0.37^{* *}$ & $4.91^{* * *}$ & 0.41 & 11.24 & 0.00 \\
\hline & $(0.23)$ & $(0.16)$ & $(0.19)$ & & & \\
\hline \multirow[t]{2}{*}{2002} & $-0.59^{* *}$ & $-0.37^{* *}$ & $4.89^{* * *}$ & 0.41 & 10.89 & 0.00 \\
\hline & $(0.24)$ & $(0.16)$ & $(0.20)$ & & & \\
\hline \multirow[t]{2}{*}{2003} & $-0.53^{* *}$ & $-0.38^{* *}$ & $4.90^{\star * *}$ & 0.41 & 11.15 & 0.00 \\
\hline & $(0.23)$ & $(0.15)$ & $(0.19)$ & & & \\
\hline \multirow[t]{2}{*}{2004} & $-0.52^{* *}$ & $-0.37^{* *}$ & $4.91^{* * *}$ & 0.40 & 10.55 & 0.00 \\
\hline & $(0.23)$ & $(0.15)$ & $(0.19)$ & & & \\
\hline \multirow[t]{2}{*}{2005} & $-0.58^{* *}$ & $-0.36^{* *}$ & $4.90^{* * *}$ & 0.40 & 10.61 & 0.00 \\
\hline & $(0.24)$ & $(0.16)$ & $(0.20)$ & & & \\
\hline \multirow[t]{2}{*}{2006} & $-0.53^{* *}$ & $-0.34^{* *}$ & $4.92^{* * *}$ & 0.38 & 9.67 & 0.00 \\
\hline & $(0.23)$ & $(0.15)$ & $(0.19)$ & & & \\
\hline \multirow[t]{2}{*}{2007} & $-0.53^{* *}$ & $-0.36^{* *}$ & $4.91^{* * *}$ & 0.38 & 9.73 & 0.00 \\
\hline & $(0.24)$ & $(0.16)$ & $(0.20)$ & & & \\
\hline \multirow[t]{2}{*}{2008} & $-0.46^{*}$ & $-0.38^{* *}$ & $4.96^{* * *}$ & 0.37 & 9.53 & 0.00 \\
\hline & $(0.23)$ & $(0.15)$ & $(0.19)$ & & & \\
\hline \multirow[t]{2}{*}{2009} & $-0.42^{*}$ & $-0.38^{* *}$ & $4.96^{* * *}$ & 0.37 & 9.21 & 0.00 \\
\hline & $(0.23)$ & $(0.15)$ & $(0.19)$ & & & \\
\hline \multirow[t]{2}{*}{2010} & $-0.42^{*}$ & $-0.36^{* *}$ & $4.97^{* * *}$ & 0.34 & 8.40 & 0.00 \\
\hline & $(0.23)$ & $(0.15)$ & $(0.19)$ & & & \\
\hline
\end{tabular}

1) Standard errors in parentheses.

\section{RCA Determinants of Spain}

For the entire period of 2000-2010, a $R C A^{s}$ variable has significantly negative correlation coefficients with RD variable (Table 14). This means that Spain exported less R\&D intensive products for the whole period. 
Table 14 Correlation Coefficients between and Industrial Characteristics Variables: 20002010

\begin{tabular}{|c|c|c|c|c|}
\hline \multirow[t]{2}{*}{ Year } & \multirow{2}{*}{$\begin{array}{l}\text { Correlation } \\
\text { Coefficients }\end{array}$} & \multicolumn{3}{|c|}{ Industrial Characteristics Variables related to $R C A^{s}$} \\
\hline & & PKL & SHKL & RD \\
\hline \multirow[t]{2}{*}{2000} & Simple & -0.17 & -0.22 & $-0.33^{*}$ \\
\hline & Spearman & -0.18 & -0.20 & $-0.55^{* * *}$ \\
\hline \multirow[t]{2}{*}{2001} & Simple & -0.17 & -0.23 & $-0.34^{* *}$ \\
\hline & Spearman & -0.19 & -0.22 & $-0.54^{* * *}$ \\
\hline \multirow[t]{2}{*}{2002} & Simple & -0.18 & -0.26 & $-0.37^{* *}$ \\
\hline & Spearman & -0.23 & $-0.29^{*}$ & $-0.58^{* * *}$ \\
\hline \multirow[t]{2}{*}{2003} & Simple & -0.15 & -0.23 & $-0.36^{* *}$ \\
\hline & Spearman & -0.22 & -0.26 & $-0.57^{* * *}$ \\
\hline \multirow[t]{2}{*}{2004} & Simple & -0.16 & -0.24 & $-0.34^{* *}$ \\
\hline & Spearman & -0.21 & -0.25 & $-0.56^{* * *}$ \\
\hline \multirow[t]{2}{*}{2005} & Simple & -0.17 & 0.26 & $-0.35^{* *}$ \\
\hline & Spearman & -0.25 & $0.30^{*}$ & $-0.55^{* * *}$ \\
\hline \multirow[t]{2}{*}{2006} & Simple & -0.15 & -0.26 & $-0.34^{* *}$ \\
\hline & Spearman & -0.21 & $-0.30^{*}$ & $-0.50^{* * *}$ \\
\hline \multirow[t]{2}{*}{2007} & Simple & -0.13 & -0.23 & $-0.33^{*}$ \\
\hline & Spearman & -0.18 & -0.25 & $-0.49^{* * *}$ \\
\hline \multirow[t]{2}{*}{2008} & Simple & -0.13 & -0.25 & $-0.34^{* *}$ \\
\hline & Spearman & -0.18 & -0.24 & $-0.51^{* * *}$ \\
\hline \multirow[t]{2}{*}{2009} & Simple & -0.13 & -0.20 & $-0.31^{*}$ \\
\hline & Spearman & -0.11 & -0.14 & $-0.46^{* * *}$ \\
\hline \multirow[t]{2}{*}{2010} & Simple & -0.08 & -0.17 & $-0.35^{* *}$ \\
\hline & Spearman & -0.10 & -0.15 & $-0.49^{* * *}$ \\
\hline
\end{tabular}

According to multiple regressions results of Spain, the coefficients of RD turn out to be significantly negative for the entire period of 2000-2010 (Table 15). This proves that Spain exported less R\&D intensive products for the whole period. 
Table 15 Multiple Regressions with $\log \left(R C A^{s}\right)$ as a Dependent Variable: 2000-2010

\begin{tabular}{|c|c|c|c|c|c|c|}
\hline \multirow{2}{*}{ Year } & \multicolumn{2}{|c|}{ Independent variables } & \multirow{2}{*}{ Constant } & \multicolumn{3}{|c|}{ Test Stat. } \\
\hline & $\log (\mathrm{SHKL})$ & $\log (\mathrm{RD})$ & & $\mathbf{R}^{2}$ & F test & Prob $>F$ \\
\hline \multirow[t]{2}{*}{2000} & -0.02 & $-0.29^{* *}$ & $4.69^{* * *}$ & 0.20 & 3.96 & 0.03 \\
\hline & $(0.18)$ & $(0.12)$ & $(0.15)$ & & & \\
\hline \multirow[t]{2}{*}{2001} & -0.05 & $-0.28^{* *}$ & $4.70^{* * *}$ & 0.21 & 4.20 & 0.02 \\
\hline & $(0.18)$ & $(0.12)$ & $(0.15)$ & & & \\
\hline \multirow[t]{2}{*}{2002} & -0.08 & $-0.30^{* *}$ & $4.69^{* * *}$ & 0.24 & 5.11 & 0.01 \\
\hline & $(0.17)$ & $(0.12)$ & $(0.15)$ & & & \\
\hline \multirow[t]{2}{*}{2003} & -0.05 & $-0.28^{* *}$ & $4.65^{\star * *}$ & 0.23 & 4.68 & 0.02 \\
\hline & $(0.17)$ & $(0.11)$ & $(0.14)$ & & & \\
\hline \multirow[t]{2}{*}{2004} & -0.06 & $-0.27^{* *}$ & $4.65^{* * *}$ & 0.21 & 4.30 & 0.02 \\
\hline & $(0.17)$ & $(0.11)$ & $(0.14)$ & & & \\
\hline \multirow[t]{2}{*}{2005} & -0.09 & $-0.25^{* *}$ & $4.65^{* * *}$ & 0.21 & 4.22 & 0.02 \\
\hline & $(0.17)$ & $(0.11)$ & $(0.14)$ & & & \\
\hline \multirow[t]{2}{*}{2006} & -0.11 & $-0.22^{*}$ & $4.64^{* * *}$ & 0.19 & 3.78 & 0.03 \\
\hline & $(0.16)$ & $(0.11)$ & $(0.14)$ & & & \\
\hline \multirow[t]{2}{*}{2007} & -0.07 & $-0.23^{* *}$ & $4.63^{* * *}$ & 0.18 & 3.48 & 0.04 \\
\hline & $(0.16)$ & $(0.11)$ & $(0.14)$ & & & \\
\hline \multirow[t]{2}{*}{2008} & -0.07 & $-0.23^{* *}$ & $4.65^{* * *}$ & 0.19 & 3.69 & 0.04 \\
\hline & $(0.16)$ & $(0.11)$ & $(0.13)$ & & & \\
\hline \multirow[t]{2}{*}{2009} & 0.01 & $-0.25^{\star *}$ & $4.66^{\star * *}$ & 0.17 & 3.24 & 0.05 \\
\hline & $(0.17)$ & $(0.11)$ & $(0.14)$ & & & \\
\hline \multirow[t]{2}{*}{2010} & 0.07 & $-0.32^{* *}$ & $4.73^{* * *}$ & 0.20 & 4.09 & 0.03 \\
\hline & $(0.18)$ & $(0.12)$ & $(0.15)$ & & & \\
\hline
\end{tabular}

1) Standard errors in parentheses.

\section{RCA Determinants of the UK}

For the entire period of 2000-2010, the results show significantly positive relationships between a $R C A^{u}$ variable and all three industrial characteristics variables (i.e., PKL, SHKL, and RD) (Table 16). ${ }^{10}$ This means that the UK exported more physical (and skilled human) capital intensive products and more R\&D intensive products for the whole period.

10 In the case of $S H K L$, a $R C A^{u}$ variable has insignificantly positive simple correlation coefficients for the entire period of 2000-2010 and insignificantly positive Spearman correlation coefficient for the year of 2010. In the case of PKL, a $R C A^{u}$ variable has insignificantly positive simple correlation coefficients for the years of 2000 and 2001. 
Table 16 Correlation Coefficients between and Industrial Characteristics Variables: 2000-2010

\begin{tabular}{c|c|c|c|c}
\hline \multirow{2}{*}{ Year } & Correlation & \multicolumn{3}{|c}{ Industrial Characteristics Variables related to $R C A^{u}$} \\
\cline { 3 - 5 } & Coefficients & PKL & SHKL & RD \\
\hline 2000 & Simple & 0.23 & 0.20 & $0.39^{* *}$ \\
& Spearman & $0.43^{* * *}$ & $0.40^{* *}$ & $0.57^{* * *}$ \\
\hline \multirow{2}{*}{2001} & Simple & 0.25 & 0.23 & $0.40^{* *}$ \\
& Spearman & $0.43^{* * *}$ & $0.38^{* *}$ & $0.59^{* * *}$ \\
\hline 2002 & Simple & $0.29^{*}$ & 0.21 & $0.35^{* *}$ \\
& Spearman & $0.41^{* *}$ & $0.36^{* *}$ & $0.59^{* * *}$ \\
\hline 2003 & Simple & $0.31^{*}$ & 0.20 & $0.36^{* *}$ \\
& Spearman & $0.46^{* * *}$ & $0.34^{* *}$ & $0.51^{* * *}$ \\
\hline 2004 & Simple & $0.30^{*}$ & 0.22 & $0.35^{* *}$ \\
& Spearman & $0.43^{* * *}$ & $0.39^{* *}$ & $0.48^{* * *}$ \\
\hline 2005 & Simple & $0.31^{*}$ & 0.21 & $0.37^{* *}$ \\
& Spearman & $0.41^{* *}$ & $0.39^{* *}$ & $0.49^{* * *}$ \\
\hline 2006 & Simple & $0.42^{* *}$ & 0.22 & $0.38^{* *}$ \\
& Spearman & $0.50^{* * *}$ & $0.33^{*}$ & $0.50^{* * *}$ \\
\hline 2007 & Simple & $0.41^{* *}$ & 0.22 & $0.35^{* *}$ \\
& Spearman & $0.51^{* * *}$ & $0.38^{* *}$ & $0.44^{* * *}$ \\
\hline 2008 & Simple & $0.42^{* *}$ & 0.26 & $0.42^{* *}$ \\
& Spearman & $0.50^{* * *}$ & $0.38^{* *}$ & $0.47^{* * *}$ \\
\hline 2009 & Simple & $0.43^{* * *}$ & 0.25 & $0.45^{* * *}$ \\
& Spearman & $0.48^{* * *}$ & $0.36^{* *}$ & $0.49^{* * *}$ \\
\hline \multirow{2}{*}{2010} & Simple & $0.34^{* *}$ & 0.23 & $0.39^{* *}$ \\
& Spearman & $0.42^{* *}$ & 0.26 & $0.44^{* * *}$ \\
\hline
\end{tabular}

According to multiple regressions results of the UK, the coefficients of RD turn out to be significantly positive for the entire period of 2000-2010 (Table 17). This proves that the UK exported more R\&D intensive products for the whole period. 
Table 17 Multiple Regressions with $\log \left(R C A^{u}\right)$ as a Dependent Variable: 2000-2010

\begin{tabular}{|c|c|c|c|c|c|c|}
\hline \multirow{2}{*}{ Year } & \multicolumn{2}{|c|}{ Independent variables } & \multirow{2}{*}{ Constant } & \multicolumn{3}{|c|}{ Test Stat. } \\
\hline & $\log (\mathrm{SHKL})$ & $\log (\mathrm{RD})$ & & $\mathrm{R}^{2}$ & $\mathrm{~F}$ test & Prob $>F$ \\
\hline \multirow[t]{2}{*}{2000} & -0.01 & $0.33^{* * *}$ & $4.19^{* * *}$ & 0.33 & 8.82 & 0.00 \\
\hline & $(0.13)$ & $(0.09)$ & $(0.11)$ & & & \\
\hline \multirow[t]{2}{*}{2001} & 0.02 & $0.34^{* * *}$ & $4.18^{* * *}$ & 0.39 & 10.35 & 0.00 \\
\hline & $(0.13)$ & $(0.09)$ & $(0.11)$ & & & \\
\hline \multirow[t]{2}{*}{2002} & -0.01 & $0.33^{* * *}$ & $4.17^{* * *}$ & 0.38 & 9.63 & 0.00 \\
\hline & $(0.13)$ & $(0.09)$ & $(0.11)$ & & & \\
\hline \multirow[t]{2}{*}{2003} & -0.02 & $0.32^{* * *}$ & $4.16^{* * *}$ & 0.33 & 7.97 & 0.00 \\
\hline & $(0.13)$ & $(0.09)$ & $(0.11)$ & & & \\
\hline \multirow[t]{2}{*}{2004} & -0.01 & $0.31^{* * *}$ & $4.16^{* * *}$ & 0.29 & 6.57 & 0.00 \\
\hline & $(0.14)$ & $(0.10)$ & $(0.12)$ & & & \\
\hline \multirow[t]{2}{*}{2005} & -0.04 & $0.30^{* * *}$ & $4.16^{* * *}$ & 0.26 & 5.56 & 0.00 \\
\hline & $(0.15)$ & $(0.10)$ & $(0.12)$ & & & \\
\hline \multirow[t]{2}{*}{2006} & -0.05 & $0.29^{* * *}$ & $4.16^{* * *}$ & 0.27 & 6.02 & 0.00 \\
\hline & $(0.14)$ & $(0.09)$ & $(0.11)$ & & & \\
\hline \multirow[t]{2}{*}{2007} & -0.01 & $0.24^{* *}$ & $4.20^{* * *}$ & 0.21 & 4.35 & 0.02 \\
\hline & $(0.14)$ & $(0.09)$ & $(0.11)$ & & & \\
\hline \multirow[t]{2}{*}{2008} & 0.01 & $0.25^{* * *}$ & $4.19^{* * *}$ & 0.25 & 5.25 & 0.01 \\
\hline & $(0.13)$ & $(0.09)$ & $(0.11)$ & & & \\
\hline \multirow[t]{2}{*}{2009} & -0.04 & $0.28^{* * *}$ & $4.15^{* * *}$ & 0.27 & 5.86 & 0.00 \\
\hline & $(0.13)$ & $(0.09)$ & $(0.11)$ & & & \\
\hline \multirow[t]{2}{*}{2010} & -0.04 & $0.25^{* * *}$ & $4.19^{* * *}$ & 0.24 & 5.04 & 0.01 \\
\hline & $(0.13)$ & $(0.09)$ & $(0.11)$ & & & \\
\hline
\end{tabular}

1) Standard errors in parentheses.

\section{Concluding Remarks}

From the above study, the following policy recommendation is suggested.

(1) For the period of 2000-2010, export products of Italy are the most concentrated. This concentration of Italian export products is followed by South Korea, France, Spain, the UK, and Germany in that order. Since this kind of high concentration of export products are not desirable, it should be diversified to avoid any potential economic loss associated with unfavorable trade-environmental changes against these concentrated export products.

(2) It was found that export patterns of South Korea changed faster than those of Germany, the UK, France, Spain, and Italy for the period of 2000-2010. On the other hand, export patterns of Italy remained the most stable in the same period. 
Therefore both South Korea and FGISU (i.e., France, Germany, Italy, Spain, and the UK in short hereafter) should fully adjust their economies to ever-changing patterns of their exports.

(3) It was found that South Korea's export patterns do not resemble those of FGISU due to the differences in factor endowment ratios of South Korea and FGISU. Therefore South Korea can increase her exports to FGISU by exploiting non-similarity of South Korean and FGISU export patterns.

(4) It was found that South Korea exported products which are less skilled human capital intensive and more R\&D intensive for the entire period of 2000-2010. France was found to have exported products which are more physical capital intensive and more R\&D intensive for most of the period. Therefore both South Korea and France should try to export more of these products to the world market from now on.

(5) It was found that Germany exported products which are more skilled human capital intensive for most of the period. Italy was found to have exported products which are less physical (and skilled human) capital intensive and less R\&D intensive for the entire period of 2000-2010. Therefore both Germany and Italy should try to export more of these products to the world market from now on.

(6) It was found that Spain exported products which are less R\&D intensive for the entire period of 2000-2010. The UK was found to have exported products which are more physical (and skilled human) capital intensive and more R\&D intensive for the entire period of 2000-2010. Therefore both Spain and the UK should try to export more of these products to the world market from now on.

The above conclusions were drawn based on the research conducted; however it has its own limitations. Therefore a more in-depth study on this topic should be pursued in the near future. 